\title{
Induced pluripotent stem cells: a new tool for toxicology screening?
}

\author{
Boon Chin Heng • Mark Richards • \\ Yimin Shu $\cdot$ Philip Gribbon
}

Received: 16 December 2008 / Accepted: 16 February 2009 / Published online: 27 February 2009

(C) Springer-Verlag 2009

In recent years, stem cells have generated much interest as a potential tool for pharmacological and toxicology screening (CIRM 2008; ABPI 2008), due to various shortcomings of currently utilized assay models based on established cell lines, primary explanted somatic cells and laboratory animals (Cao et al. 2008; Vinoth et al. 2008). In vitro toxicology screening most commonly utilize established cell lines of cancerous/tumorigenic origin, that are highly adapted to in vitro culture conditions after countless passages, and which contain chromosomal and genetic aberrations that render them immortal (Phelps et al. 1996). Such inherent deficiencies make them non-representative of how a normal cell behaves physiologically in vivo. Indeed, it is common knowledge that immortalized transformed cell lines are more robust, proliferates faster, and have much less fastidious nutritional requirements compared to primary somatic cells explanted from living tissues (Phelps et al. 1996).

Hence it may be preferable to utilize primary explanted cultures of somatic cells for toxicology screening, but these

B. C. Heng ( $\square)$

Abbott Vascular Inc., 3200 Lakeside Drive,

Santa Clara, CA 95054, USA

e-mail: boonchinheng@gmail.com

\section{Richards}

School of Chemical and Life Sciences,

Nanyang Polytechnic, 180 Ang Mo Kio Avenue 8,

Singapore 569830, Singapore

Y. Shu

Stanford University Medical Center,

900 Welch Road ST 14, Palo Alto, CA 94304, USA

P. Gribbon

European Screening Port GmbH,

Schnackenburgallee 114, 22525 Hamburg, Germany often are heterogeneous cultures that display a high degree of inter-batch variability, making it challenging to obtain consistent and reproducible results in toxicology screening (Cao et al. 2008; Vinoth et al. 2008). Additionally, primary cell cultures of human origin often suffer from inconsistent availability, depending on the will of patients to donate. It is often the case that primary cultures are established from discarded human tissues of pathological origin, which would skew their response to toxic challenge. Moreover, one of the main logistical improvements realized in cellbased screening in recent years has been the introduction of batch-based cryopreserved cell preparations in high throughput screening, which have greatly improved reproducibility in assay performance (Zaman et al. 2007). However, due to a high degree of heterogeneity and interbatch variability in primary explanted somatic cells, these often display much inconsistency in their post freeze-thaw viability and metabolic activity unlike established cell lines (Zaman et al. 2007), which could further confound the reproducibility and accuracy of screening assays based on primary explanted somatic cells. The logistical challenges of high throughput cell based assays cannot be underestimated and the introduction of any new screening paradigms needs to be accompanied by robust and practical working practices, conditions that are difficult to be met with primary explanted somatic cells.

Live animal models could provide yet another alternative for toxicology screening, but have a number of inherent flaws. First, an animal model may not compare well with human physiology. Second, the use of live animals in routine toxicology screening of biomedical and cosmetic products may be ethically contentious, and can possibly affect consumer confidence. Last, live animals are expensive to purchase and maintain compared to in vitro cultured cells. 
Stem cells utilized for toxicology screening can be of adult, fetal or embryonic origin (Weissman 2000; Zeng and Rao 2008). Nevertheless, the ability of human embryonic stem cells (hESC) to be propagated indefinitely within in vitro culture, offers a distinct advantage over primary cultures of fetal and adult stem cells that would invariably become senescent after a limited number of passages ex vivo. Because hESC lines are theoretically 'immortal', provided that appropriate culture conditions for their propagation are continuously maintained (Skottman et al. 2007), these can provide an almost limitless supply of cells from the same batch that would yield consistent and reproducible results in toxicology screening assays. The pluripotency of hESC provides yet another major advantage. Because different somatic lineages would be expected to respond differently to the same toxic challenge, it may be necessary to screen more than one differentiated cell type in order to validate the safety of a particular substance that would come into direct contact with the human body. Whilst adult and fetal stem cells are highly restricted in their differentiation potential, the almost unrestricted ability of hESC to differentiate into any of the 200 or more somatic lineages within the human body (Ohtsuka and Dalton 2008) can potentially provide a multitude of different cell types for toxicology screening.

Nevertheless, the application of hESC in experimental research and therapy (Mauron and Jaconi 2007; Waite and Nindl 2003) is fraught with ethical and moral controversy (Mauron and Jaconi 2007; Waite and Nindl 2003), which in turn has sparked much heated debate and enactment of restrictive legislation in several countries (Childress 2004; Mertes et al. 2008). The key issue of contention is the perception that human life begins at the onset of fertilization (Young 1994; Sullivan 2003), so that the termination of embryos for the isolation of new hESC lines would represent wanton and willful destruction of human life (Araujo 2006). The aim here is neither to dispute nor debate legal, ethical and moral issues pertaining to hESC research and application. Instead, the focus is on the sociological impact of utilizing hESC for toxicology screening of various biomedical and cosmetic products intended for human use. There is a risk that this might undermine consumer confidence in a large segment of the population that hold a negative perception of hESC research. After all, it must be remembered that the marketability and commercial success of a product is ultimately dependent on consumer confidence and goodwill. Prominent examples of products that have lost a significant degree of consumer confidence and goodwill as a result of vigorous campaigning and lobbying by a vocal minority include animal fur apparels (The Economist 2001), cosmetics that rely on animal testing (Kuehn 2003), and food produced by factory-farming (Holdrege 2007)
Recently, the successful reprogramming of adult somatic cells into an embryonic stem cell-like state through genetic manipulation (Yu et al. 2007; Takahashi et al. 2007), opens up a new opportunity for toxicology assay development that is free of ethical and moral controversy, unlike the derivation of hESC lines from human embryos. Two research groups, one in the USA ( $\mathrm{Yu}$ et al. 2007) and the other in Japan (Takahashi et al. 2007), achieved this breakthrough concurrently, even though there was some variation in their methodology. Whilst the study by $\mathrm{Yu}$ and colleagues in the USA (Yu et al. 2007) utilized lentiviral-mediated expression of four genes: Oct4, Sox2, Nanog, and Lin28; the study by Takahashi and colleagues in Japan (Takahashi et al. 2007) utilized retroviral transduction of Oct3/4, Sox 2 , $\mathrm{Klf} 4$, and c-Myc. The reprogrammed somatic cells, referred to as induced pluripotent stem cells (iPSC) possess characteristics that are very similar, if not identical to hESC ( $\mathrm{Yu}$ et al. 2007; Takahashi et al. 2007). However, there are two major challenges faced in utilizing iPSC for toxicology screening assays.

First, it is currently unknown how the epigenetic state of reprogrammed iPSC actually compares with hESC derived from 'normal' human blastocyst-stage embryos (Surani et al. 2008; Han and Sidhu 2008). There is a possibility that subtle differences in the epigenetic programming of iPSC and hESC might in turn lead to differences in their response to toxic challenge. This certainly requires further investigation. Presently, a commonly held view is that the epigenetic signature of hESC represents the 'gold standard' due to it's origin from normal human embryos; and that any differences in epigenetic programming of iPSC compared to $\mathrm{hESC}$ must therefore represent some form of aberration that would set it apart from normal cells. Nevertheless, this view is disputable because comparison of various hESC lines have in fact demonstrated much variability in epigenetic programming (Allegrucci and Young 2007; Rugg-Gunn et al. 2007), and it is therefore uncertain which of these represent the correct 'gold standard' epigenetic signature that iPSC should ideally possess. Moreover, with the exception of embryotoxicity and teratogenicity testing, it is unlikely that toxicology screening will be carried out directly on undifferentiated iPSC or hESC, but would instead utilize their differentiated somatic progenies. It that case, it may possibly be more advantageous to utilize iPSC rather than hESC, because iPSC being reprogrammed somatic cells, may more easily revert back to their original somatic epigenetic signature, whereas hESC lines do not have an original somatic epigenetic signature to revert back to. For example, if a particular toxicology assay would require mature skin epithelium, then it may be advantageous to utilize differentiated epithelial progenies of iPSC lines that were originally derived from skin, as it is speculated that the epigenetic signature of such cells would more 
closely resemble that of adult skin, as compared to hESCderived epithelial progenies. In the future, it is possible that iPSC lines for toxicology screening may also be derived from the reprogramming of primary explanted hepatocytes and cardiomyocytes, because such somatic lineages have wide-ranging applications in both toxicology and pharmacology screening.

Second, another major challenge is that the derivation of iPSC entails permanent genetic modification to somatic cells, due to the use of viral transduction of recombinant DNA (Yu et al. 2007; Takahashi et al. 2007). Integration of recombinant DNA within the genome of iPSC lines might cause these cells or their differentiated progenies to behave differently from normal unmodified human cells, particularly when exposed to toxic challenge. Of particular concern is the possibility that the differentiated progenies of iPSC might acquire the 'cancer-like' properties of established cell lines, which would lessen their predicative value in toxicology screening. Indeed, previous human clinical trials on gene therapy have resulted in the development of cancer in the unfortunate patient (Hacein-Bey-Abina et al. 2008), which has been blamed on mutagenesis induced by random insertion of recombinant DNA within the host genome. Nevertheless, there has recently been much progress in the development of new strategies for iPSC derivation that avoid integration of recombinant DNA within the host cell genome. These include the use of adenoviral vectors (Stadtfeld et al. 2008a), plasmids (Okita et al. 2008) and small molecules involved in the wnt signaling pathway (Marson et al. 2008). A more intriguing and novel alternative would be the direct delivery of transcription factors to the cytosol (Heng and Richards 2008; Heng et al. 2005), either with protein transduction domains (Heng and Cao 2005) or immunoliposomes (Sullivan et al. 1986), thus completely avoiding the use of recombinant DNA and genetic manipulation altogether. Although the delivered transcription factors will only have a limited active half-life in the cytosol, this is not implausible given that transgene expression is required only for the first 10-12 days of the reprogramming process for iPSC derivation (Brambrink et al. 2008; Stadtfeld et al. 2008b).

It is imperative that these two pertinent challenges be addressed prior to further research on the potential use of iPSC in toxicology screening. Because iPSC lines can be isolated from a diverse range of human individuals with well-characterized adult phenotypes, these can potentially provide a valuable tool for characterizing how variation in toxic susceptibility displayed by different individuals correlates to their genetics, disease state and other observable phenotype. By contrast, such an opportunity does not exist with hESC lines because of the unknown and uncharacterized adult phenotype of pre-implantation embryos from which these cells are isolated. iPSC lines may also be created by reprogramming diseased human cells. Diseasespecific iPSC lines will be invaluable tools that allow scientists to watch the development of diseases in vitro, outside the patient's body. Indeed, iPSC lines representative of a variety of human genetic diseases such as Parkinson's disease, Down's syndrome and Type 1 diabetes mellitus have already been created (Park et al. 2008). These cell lines represent an unprecedented opportunity to recapitulate both normal and pathological tissue formation in vitro, thereby facilitating drug development, toxicology screening, gene therapy and pathological investigation. Additionally, due to ethical and moral controversy surrounding the research and application of hESC lines, iPSC represent a much preferred alternative that is free of the political and legislative baggage accompanying hESC. Rapid progress and increasing scientific research in the iPSC field, together with the development of new technology platform give cause for optimism that the two major challenges discussed can be overcome in the near future.

\section{References}

ABPI (2008) Stem cells in predictive toxicology. A report of a scoping study from the Stem Cells in Predictive Toxicology Task Force, for the Department of Health and the Department of Trade and Industry, United Kingdom. Prepared by The Association of the British Pharmaceutical Industry (ABPI). http://www.sc4sm.org/ downloads/SC4PT-REPORT.pdf. Accessed 5 Dec 2008

Allegrucci C, Young LE (2007) Differences between human embryonic stem cell lines. Hum Reprod Update 13(2):103-120

Araujo RJ (2006) The transnational perspective of the church: the embryonic cloning debate \& stem cell research. J Contemp Health Law Policy Spring 22(2):497-507

Brambrink T, Foreman R, Welstead GG et al (2008) Sequential expression of pluripotency markers during direct reprogramming of mouse somatic cells. Cell Stem Cell 2:151-159

Cao T, Lu K, Fu X, Heng BC (2008) Differentiated fibroblastic progenies of human embryonic stem cells for toxicology screening. Cloning Stem Cells 10(1):1-10

Childress JF (2004) Sources of stem cells: ethical controversies and policy developments in the United States. Fetal Diagn Ther 19(2):119-123

CIRM (2008) Stem cells in predictive toxicology. California Institute of Regenerative Medicine (CIRM), workshop report, 7-8 July 2008. http://www.cirm.ca.gov/pub/pdf/CIRM_Predictive_Tox. pdf. Accessed 5 Dec 2008

Hacein-Bey-Abina S, Garrigue A, Wang GP, Soulier J, Lim A, Morillon E, Clappier E, Caccavelli L, Delabesse E, Beldjord K, Asnafi V, MacIntyre E, Dal Cortivo L, Radford I, Brousse N, Sigaux F, Moshous D, Hauer J, Borkhardt A, Belohradsky BH, Wintergerst U, Velez MC, Leiva L, Sorensen R, Wulffraat N, Blanche S, Bushman FD, Fischer A, Cavazzana-Calvo M (2008) Insertional oncogenesis in 4 patients after retrovirus-mediated gene therapy of SCID-X1. J Clin Invest 118(9):3132-3142

Han J, Sidhu KS (2008) Current concepts in reprogramming somatic cells to pluripotent state. Curr Stem Cell Res Ther 3(1):66-74

Heng BC, Cao T (2005) Incorporating protein transduction domains (PTD) within intracellular proteins associated with the 'stemness' phenotype. Novel use of such recombinant 'fusion' proteins to 
overcome current limitations of applying autologous adult stem cells in regenerative medicine? Med Hypotheses 64(5):992-996

Heng BC, Richards M (2008) Induced pluripotent stem cells (iPSC) can direct delivery of transcription factors into the cytosol overcome the perils of permanent genetic modification? Minim Invasive Ther Allied Technol 17(5):326-327

Heng BC, Hong YH, Cao T (2005) Modulating gene expression in stem cells without recombinant DNA and permanent genetic modification. Cell Tissue Res 321(2):147-150

Holdrege C (2007) Blame factory farming, not organic food. Nat Biotechnol 25(2): 165 discussion 165-6

Kuehn BM (2003) The EU bans cosmetics testing on animals. J Am Vet Med Assoc 222(5):559

Marson A, Foreman R, Chevalier B, Bilodeau S, Kahn M, Young RA, Jaenisch R (2008) Wnt signaling promotes reprogramming of somatic cells to pluripotency. Cell Stem Cell 3(2):132-135

Mauron A, Jaconi ME (2007) Stem cell science: current ethical and policy issues. Clin Pharmacol Ther 82(3):330-333

Mertes H, Pennings G (2008) Cross-border research on human embryonic stem cells: legal and ethical considerations. Stem Cell Rev. 4 Dec 2008 [Epub ahead of print]

Ohtsuka S, Dalton S (2008) Molecular and biological properties of pluripotent embryonic stem cells. Gene Ther 15(2):74-81

Okita K, Nakagawa M, Hyenjong H, Ichisaka T, Yamanaka S (2008) Generation of mouse induced pluripotent stem cells without viral vectors. Science 322(5903):949-953

Park IH, Arora N, Huo H, Maherali N, Ahfeldt T, Shimamura A, Lensch MW, Cowan C, Hochedlinger K, Daley GQ (2008) Disease-specific induced pluripotent stem cells. Cell 134(5):877886

Phelps RM, Johnson BE, Ihde DC, Gazdar AF, Carbone DP, McClintock PR, Linnoila RI, Matthews MJ, Bunn PA Jr, Carney D, Minna JD, Mulshine JL (1996) NCI-Navy Medical Oncology Branch cell line data base. J Cell Biochem Suppl 24:32-91

Rugg-Gunn PJ, Ferguson-Smith AC, Pedersen RA (2007) Status of genomic imprinting in human embryonic stem cells as revealed by a large cohort of independently derived and maintained lines. Hum Mol Genet 16 Spec No. 2:R243-R251

Skottman H, Narkilahti S, Hovatta O (2007) Challenges and approaches to the culture of pluripotent human embryonic stem cells. Regen Med 2(3):265-273
Stadtfeld M, Nagaya M, Utikal J, Weir G, Hochedlinger K (2008a) Induced pluripotent stem cells generated without viral integration. Science 322(5903):945-949

Stadtfeld M, Maherali N, Breault DT et al (2008b) Defining molecular cornerstones during fibroblast to iPS cell reprogramming in mouse. Cell Stem Cell 2:230-240

Sullivan DM (2003) The conception view of personhood: a review. Ethics Med 19:11-33

Sullivan SM, Connor J, Huang L (1986) Immunoliposomes: preparation, properties, and applications. Med Res Rev 6(2):171-195

Surani MA, Durcova-Hills G, Hajkova P, Hayashi K, Tee WW (2008) Germ line, stem cells, and epigenetic reprogramming. Cold Spring Harb Symp Quant Biol. 6 Nov 2008. [Epub ahead of print]

Takahashi K, Tanabe K, Ohnuki M, Narita M, Ichisaka T, Tomoda K, Yamanaka S (2007) Induction of pluripotent stem cells from adult human fibroblasts by defined factors. Cell 131(5):861-872

The cost of fur; Fur coats and animal welfare. The Economist, March, 2001. http://findarticles.com/p/articles/mi_hb5037/is_/ai_n1827 2085. Accessed 5 Dec 2008

Vinoth KJ, Heng BC, Poonepalli A, Banerjee B, Balakrishnan L, Lu K, Hande MP, Cao T (2008) Human embryonic stem cells may display higher resistance to genotoxic stress as compared to primary explanted somatic cells. Stem Cells Dev 17(3):599-607

Waite L, Nindl G (2003) Human embryonic stem cell research: an ethical controversy in the US \& Germany. Biomed Sci Instrum 39:567-72

Weissman IL (2000) Translating stem and progenitor cell biology to the clinic: barriers and opportunities. Science 287(5457):14421446

Young K (1994) The zygote, the embryo, and personhood: an attempt at conceptual clarification. Ethics Med 10:2-7

Yu J, Vodyanik MA, Smuga-Otto K, Antosiewicz-Bourget J, Frane JL, Tian S, Nie J, Jonsdottir GA, Ruotti V, Stewart R, Slukvin II, Thomson JA (2007) Induced pluripotent stem cell lines derived from human somatic cells. Science 318(5858):1917-1920

Zaman GJ, de Roos JA, Blomenröhr M, van Koppen CJ, Oosterom J (2007) Cryopreserved cells facilitate cell-based drug discovery. Drug Discov Today 12(13-14):521-526

Zeng X, Rao MS (2008) Controlled genetic modification of stem cells for developing drug discovery tools and novel therapeutic applications. Curr Opin Mol Ther 10(3):207-213 